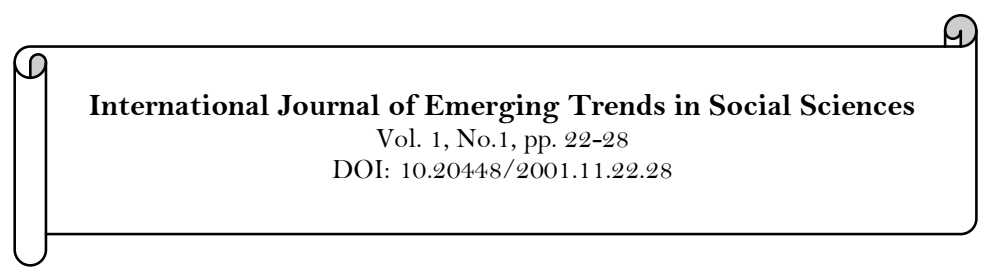

\title{
Effect of Ethno-Religious Crises on the Infrastructure of Wukari Town, Taraba State, Nigeria
}

\author{
Abuh, Paul Ojochenemi ${ }^{1}$ \\ Joseph Lovely Amayll ${ }^{2}$ \\ Joshua Ogwuche ${ }^{3}$ \\ 1,2Department of Geography, Kwararafa University, Wukari, Taraba State, Nigeria. \\ ${ }^{3}$ Department of Public Administration, Kwararafa University, Wukari, Taraba State, Nigeria.
}

\begin{tabular}{|c|c|}
\hline Abstract & \\
\hline $\begin{array}{l}\text { The study is aimed at Effect of Ethno-Religious Crises on the } \\
\text { Infrastructures of Wukari Town in Taraba State. Using Cochran } \\
(1977) \text { method of sample size determination, a total of } 196 \\
\text { questionnaire was distributed to respondents. A total of forty (40) } \\
\text { copies of the questionnaire was distributed each to T-Junction, } \\
\text { Wapan Nghaku, Old BB and Mission areas. And thirty (30) was } \\
\text { distributed to GRA extension. Purposeful and stratified sampling } \\
\text { technique was use and the head of household or next elderly literate } \\
\text { person in a household was the respondent. Descriptive statistics were } \\
\text { used to analyse the data and the research covers the period of crises } \\
\text { that occurred around } 2012-2015 \text { in Wukari town. The study } \\
\text { indicates that housing is the most affected infrastructures with } \\
\text { (43.39\%). And this is responsible for out-migration and reduction of } \\
\text { economic activities in the area. Also, the study reveals that the effect } \\
\text { of the crises on infrastructures include decay and destruction of } \\
\text { infrastructures (29.63\%), inadequate manpower(28.04\%), increase in } \\
\text { rents(22.22\%), and difficult banking services(20.11\%). The study } \\
\text { therefore, suggests religious tolerance, public enlightenment, } \\
\text { discouragement of formation of ethnic militia and avoidance of } \\
\text { mutual suspicion as a way of mitigating crises. The study concludes } \\
\text { that peace remains the only factor for development. As such, all } \\
\text { stakeholders must put in their best to ensure continuous co-existence } \\
\text { among the people. }\end{array}$ & $\begin{array}{l}\text { Licensed: } \\
\text { This work is licensed under a } \\
\text { Creative Commons Attribution } \\
\text { 4.0 License. } \\
\text { Publisher: } \\
\text { Scientific Publishing Institute }\end{array}$ \\
\hline
\end{tabular}

\section{Introduction}

For decades now, Nigeria has been plunged into a constant violent activity of communal disputes. Hitherto peaceful communities are at each other's throat. Peoples that have cohabited peacefully in some instances for over a century are up in arms against each other (Mukhtar, Arooj, Ashfaq, \& Gulzar, 2017).

The Nigerian State, just as others in Africa, has been blamed for its inability to develop a way to accommodate the various ethnic groups that make up the country. Rather, Nigeria's post-colonial policies fracture and dismember Nigerians, thereby sustaining bickering relations between its varied groups (Adejumobi, 2001).

These conflicts are as a result of many fundamental issues. Specifically, the interplay of economic imbalance, political injustice, ethnic chauvinism (eagerness for national superiority), religious intolerance, and the nature of the global economy (Mukhtar et al., 2017).

There have been several ethno-religious crises in Nigeria. The Maitatsine religious disturbances of 1980's, Zango-Kataf crises of 1992 and Tafawa Balewa crises of 2001 among others. The impact on both political and socio-economic sphere is unimaginable as this has led to the destruction of life and property.

Wukari Local Government Area is one among the 774 local government councils in Nigeria witnessing ethno-religious crises since 1991. The rate of the crises in Wukari has caused high rate of deaths, injuries and destruction of properties and has severely disrupted most economic activities.

Charles, Andeshi, and Daniel (2014) defined ethno-religious violence as a state of affairs in which the relationship between members of one ethnic or religious group and another of such group in a multi-ethnic 
and multi-religious society is characterized by lack of cordiality, mutual suspicion, fear, and a tendency towards violent confrontation. The spate of the ethno religious violence should be a matter of deep concern to researchers, guidance counsellors and peace lovers all over the country.

Ali (2008) asserted that Nigeria has witnessed a series of crises which most often have religious, political and ethnic dimensions. These crises have led to the destruction of lives and property, and in most cases, hindered or stowed down socio-economic activities such as farming, trading, education and enrolment rates, and housing and settlement patterns among others.

Several factors can be held accountable for the profusely widespread of ethno-religious crises in Nigeria. As observed by Alfa (2012) the major causes of ethno-religious crises in Nigeria can be attributed to the overbearing character of the post-colonial Nigeria state, greed, selfishness, parochialism, pettiness and irresponsible conduct by those who are supposed to be leaders.

Weak national security system is also one of the factors responsible for ethnic and religious conflicts in Nigeria. The lack of security policy to a reasonable extent has undermined the capacity of the country to confront ethno-religious crisis whenever they arise (Ebukelo, 2010).

According to Mohammed (2013) the body language and actions of all the regions in Nigeria claim to be marginalized. Crises of ethnic nationalism and calls for national conference, a new dimension in the issue are the increasing recruitment of ethnic militia with reckless abandon.

Conflicts can have series of impacts on the development of a place which can be long-term or short-term. The effects are felt at various spatial levels, within the immediate environment where the conflict take place and often in the surrounding environment.

The Department for International Development (DFID) 2001 reports that in the 20 years from 1980 to 2000, Africa lost over 50 per cent of its infrastructure as a result of conflict

Infrastructure refers to the fundamental facilities and systems serving a country, city, or area, including the services and facilities necessary for its economy to function. It typically characterizes technical structures such as roads, bridges, tunnels, water supply, sewers, electrical grids, telecommunications, and so forth, and can be defined as "the physical components of interrelated systems providing commodities and services essential to enable, sustain, or enhance societal living conditions. It refers to structures, systems, and facilities serving the economy of a business, industry, country, city, town or area, including the services and facilities necessary for its economy to function (Sullivan \& Steven, 2003).

"Infrastructure" has been defined as "the basic structures and facilities necessary for a country or an organization to function efficiently, example buildings, transport, water and energy resources, and administrative systems (Hornby, 1995). Infrastructures are the criteria for the success of public and private efforts aimed at accelerating economic development (Egbetokun, 2009). Also, Omofonmwan (2004) asserted that one of the critical factors that contributed to the high level of rural poverty is the inadequate infrastructural facilities. This is supported by United Nations (2011) that infrastructure plays a critical role in poverty reduction, economic growth and employment of the masses.

There are different types of infrastructure: Physical (water pipes, roads), Social (houses, clinics, sports grounds, and schools), Economic (business districts, transport systems, telephones) (ETU Local government toolkit).

During crises destruction of life and properties is observed. In the last two decades there have been persistent crises of religious dimension in Wukari. These crises have led to significant displacement of people. However, not many studies have been carried out to assess the effects of these crises/conflicts on the infrastructures of the town. Therefore, the research will focus on the effect of ethno-religious crises on the infrastructures of Wukari Town in Taraba State.

\section{Study Area}

\subsection{Population, Location, Position and Size}

Wukari is a Local Government Area in Taraba State, Nigeria. It lies within latitude $7^{\circ} 51^{\prime} \mathrm{N}$ of the equator and $9^{\circ} 47^{\prime} \mathrm{E}$ of the meridian with the land area of approximately $4,308 \mathrm{~km}^{2}$. The Donga River flows through the area. It is located in the southern part of Taraba state. Wukari has ten (10) political wards namely: Akwana, Avyi, Bantaje, Chonku, Hospital, Jibu, Kente, Puje, Rafin Kada and Tsokundi wards.

Wukari has a total land mass of $4391.812 \mathrm{~km}^{2}$ and a total population of Two Hundred and Thirty Eight Thousand, Two Hundred and Eighty Three (238283) people. (National Population Commission, 2010)

It is bordered with Takum to the South, Donga to the East, Ibi to the North, at the west with Ukum local government area of Benue state and Gassol to the North-East. 


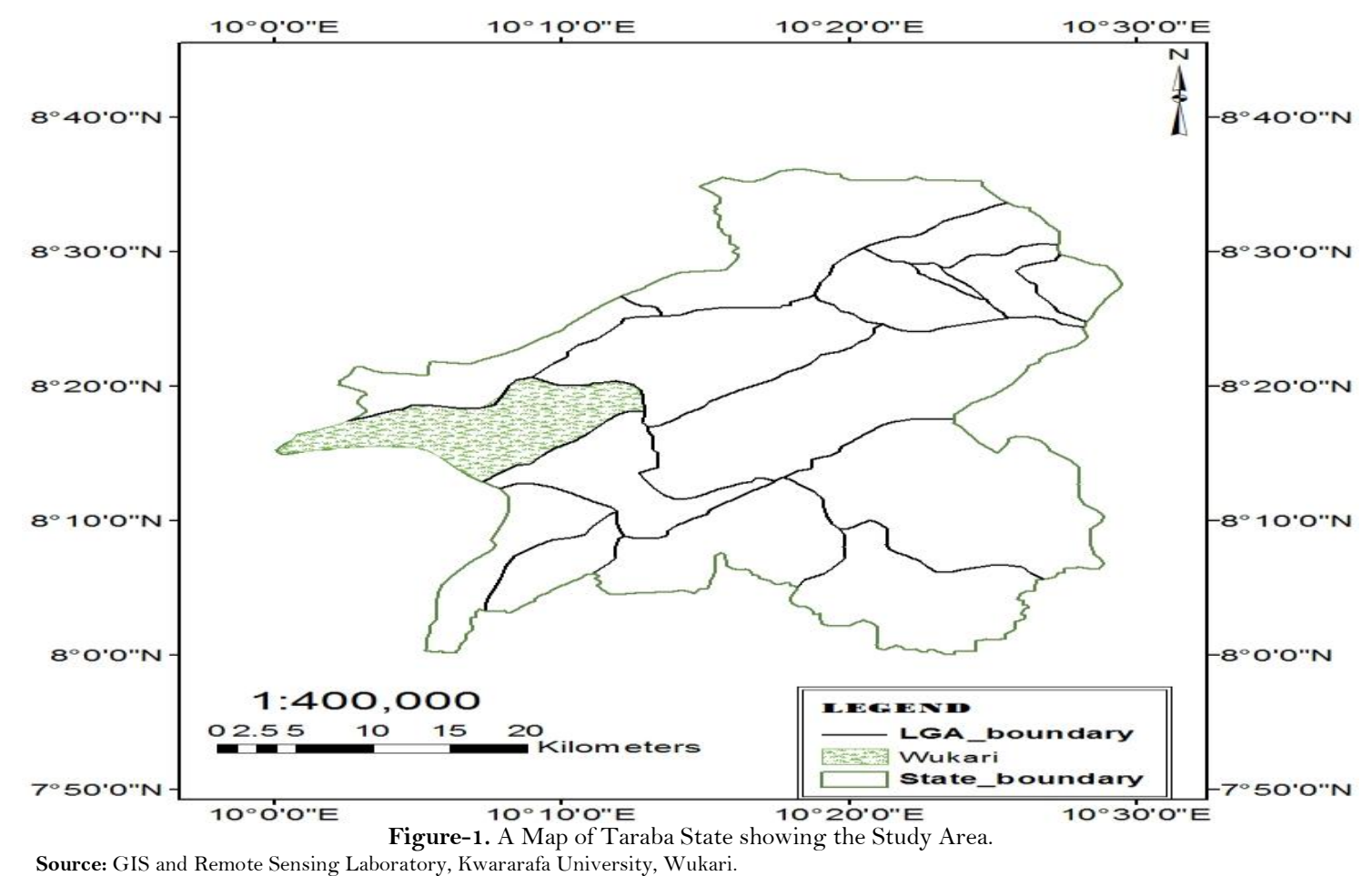

Source: GIS and Remote Sensing Laboratory, Kwararafa University, Wukari.

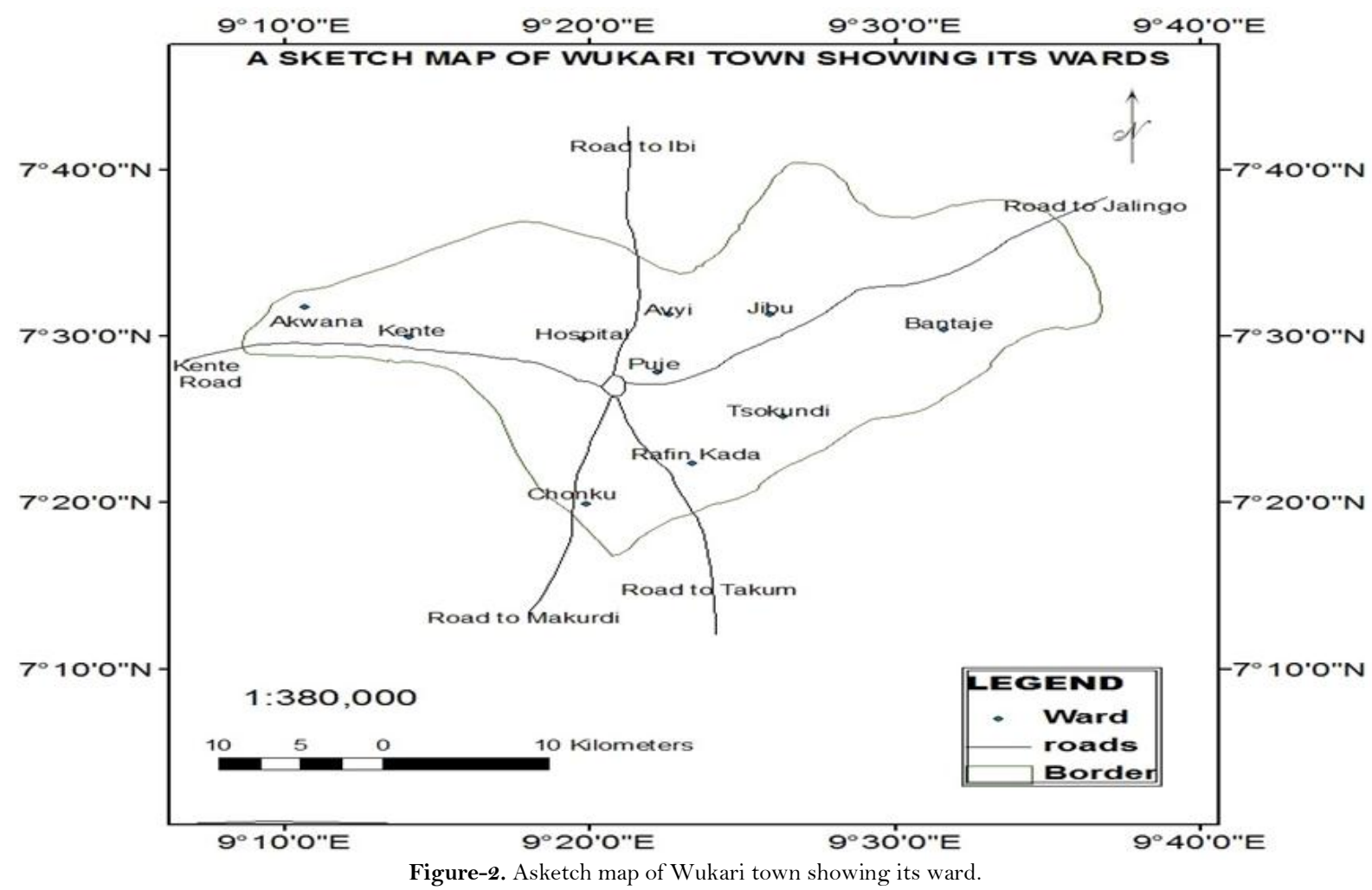

Source: GIS and Remote Sensing Lab, Kwararafa University Wukari.

\section{Methodology}

The sample size was calculated based on the sample required to estimate a proportion with an approximate 95\% confidence level. The formula used for this research was put forward by Cochran (1977)

$$
\frac{\mathrm{n}=\mathrm{Z}^{2} \mathrm{Pq}}{\mathrm{e}^{2}}
$$

Where $\mathrm{n}=$ required sample size, $\mathrm{p}=$ proportion of the population having the characteristic, $\mathrm{q}=1-\mathrm{p}$ and $\mathrm{e}=$ the degree of precision. The proportion of the population $(p)$ may be known from prior research or other sources; if it is unknown use $p=0.5$. The degree of precision (e) is the margin of error that is 
acceptable. Setting e $=0.07$, would give a margin of error of plus or minus $7 \% . Z=$ is the selected critical value of desired confidence level. Therefore, the calculation for required sample size will be as follows $p=0.5, q=1-$ $0.5=0.5, \mathrm{e}=0.05$ or $\pm 5 \%, \mathrm{Z}=1.96(95 \%$ confidence level $)$

$$
\begin{gathered}
\mathrm{n}=\frac{(1.96)^{2}(0.5)(0.5)}{0.07^{2}} \\
\mathrm{n}=\frac{(3.8416)(0.25)}{0.0049} \\
=196
\end{gathered}
$$

The sample size calculated is 196. Therefore, 196 respondents in the selected areas of Wukari town were selected for the study. Forty (40) copies of the questionnaire will be distributed each to T-Junction, Wapan Nghaku, Old BB, and Mission areas. And thirty-six (36) to be distributed in GRA Extension.

The Sampling technique used was purposeful and stratified sampling where respondents were household heads and next elderly literate person in a household. And the basic research instrument used was the questionnaire. Also, primary and secondary sources of data collection were used. The research covers the recent crises that occurred around 2012-2015.

The method of data analysis involves the use of descriptive statistics such as simple percentage, charts and tables in the summary and interpretation of the data collected.

\section{Result and Discussion}

\subsection{Demographic and Socio Economic Characteristics}

The demographic and socio-economic characteristics of the respondent will be discussed. This involves the gender, education, marital status and occupation.

\begin{tabular}{l|l|l}
\multicolumn{3}{c}{ Table-1. Demographic and Socio Economic Characteristics of Respondents. } \\
\hline Description & Frequency(189) & Percentage (\%) \\
\hline Gender & 115 & 60.85 \\
\hline Male & 79 & 39.15 \\
\hline Education & & \\
\hline None & 8 & 4.23 \\
Primary Education & 7 & 3.70 \\
Secondary Education & 52 & 27.51 \\
Tertiary Education & 122 & 64.55 \\
\hline Marital Status & & \\
\hline Single & 75 & 39.68 \\
Married & 95 & 50.26 \\
Widow/Widower & 14 & 7.41 \\
Divorce/Separated & 5 & 2.65 \\
\hline Occupation & & \\
\hline Civil Servants & 72 & 38.09 \\
Unskilled worker & 15 & 7.94 \\
Business Men/Women & 49 & 25.93 \\
Agriculture & 19 & 10.05 \\
Skilled Worker & 16 & 8.47 \\
Professional & 18 & 9.52 \\
\hline Soure FilSwey & & \\
\hline
\end{tabular}

Source: Field Survey, 2016

Table 1 above shows the male gender with $60.85 \%$ and the female gender $39.15 \%$. This indicates that majority of the respondents were male which is as a result of the respondents being household heads, this is so also because household heads are usually males in most African setting.

The distribution of respondents according to their literacy level indicates that the respondents with higher educational attainment were the majority with $64.55 \%$ followed by persons with secondary school certificates with $27.51 \%$, persons with no educational attainment having $4.23 \%$ and primary school certificate holders having $3.70 \%$. This is not surprising as Wukari is the only town in the North-East of Nigeria with three universities.

Likewise, the distribution of respondents based on their marital status shows that $39.68 \%$ were single, $50.26 \%$ were married, $2.65 \%$ were divorced or separated and 7.41 widowed. This suggests that majority of the respondents were married. 
Also, the Table indicates that majority of the respondents were Civil Servants (38.09\%) followed by Business men and women (25.93\%), Agricultural Producers (10.05\%), Professionals (9.52\%), Skilled Workers $(8.47 \%)$ and Unskilled Workers (7.94\%). This suggest that Wukari is becoming an emerging urban center.

\subsection{Causes of Ethno-Religious Crises}

The view of the respondents on the causes of enthno-religious crises was sought and analyzed.

Table-2. Respondents View on Possible Cause of Ethno-religious Crises.

\begin{tabular}{l|l|l}
\hline Possible Cause & Frequency & Percentage \\
\hline Political Interference & 40 & 21.16 \\
Religious Intolerance and Fanaticism & 78 & 41.27 \\
Religious Teachings & 51 & 26.98 \\
Poverty & 9 & 4.76 \\
Weak National Security & 7 & 3.70 \\
Recruitment of Ethnic Militia & 4 & 2.12 \\
\hline Total & 189 & 100.0 \\
\hline Source: Field work, 2016 &
\end{tabular}

Table 2 shows respondents' view on the possible cause of the ethno-religious crises that happened from 2012 to 2015 in Wukari town. The Table indicates that religious intolerance and fanaticism is the major cause of the crisis having $(41.27 \%)$, religious teachings $(26.98 \%)$, political interference $(21.6 \%)$, poverty $(4.76 \%)$, weak national security $(3.70 \%)$ and recruitment of ethnic militia having $2.12 \%$. This correlates with the findings of Ali (2008); Mukhtar et al. (2017) that the interplay of economic imbalance, political injustice, ethnic chauvinism and religious intolerance are the fundamental issues leading to crises.

\subsection{Infrastructures of Wukari Town}

Several infrastructural facilities are identified in Wukari town. Table 3 indicates respondents' view on the availability of infrastructural facilities in Wukari town.

Table-3. Distribution of Respondents by Response on the Infrastructures of Wukari Town.

\begin{tabular}{l|l|l}
\hline Infrastructures & Frequency & Percentage \\
\hline Public Library & 18 & 9.52 \\
Education & 45 & 23.81 \\
Housing & 22 & 11.64 \\
Health Facilities & 42 & 22.22 \\
Electricity & 34 & 17.99 \\
Banking and Insurance Facilities & 6 & 3.17 \\
Road & 9 & 4.76 \\
Post Office & 13 & 6.88 \\
\hline Total & 189 & 100.0 \\
\hline Source: Field work, 2016. &
\end{tabular}

Table 3 shows that the most available infrastructure of Wukari town is Education (23.81\%). It is followed with Health facilities (22.22\%), Electricity (17.99\%), Housing (11.64\%), Public Library (9.52\%), Post Office (6.88\%), Road (4.76\%), and Banking and Insurance Facilities $(3.17 \%)$ respectively.

\subsection{Effects of Ethno-Religious Crises on the Infrastructures of Wukari Town}

The following table shows data on the most affected infrastructures as a result of these crises.

Table-4. Response on Most Affected Infrastructures after Crises.

\begin{tabular}{l|l|l}
\hline Most Affected Infrastructures & Frequency & Percentage \\
\hline Education & 42 & 22.22 \\
Housing & 82 & 43.39 \\
Health Facilities & 3 & 1.59 \\
Electricity & 17 & 8.99 \\
Banking and Insurance Facilities & 45 & 23.81 \\
\hline Total & 189 & 100.0 \\
\hline Source: Field work, 2016. &
\end{tabular}

Table 4 shows that Housing is the most affected infrastructures with $(43.39 \%)$. It is followed with Banking and Insurance Facilities (23.81\%), Education (22.22\%) and Health (1.59\%) respectively. This has led to out-migration and reduction of economic activities in the area.

Response on Impact of Ethno-religious Crises on Infrastructures of Wukari town 


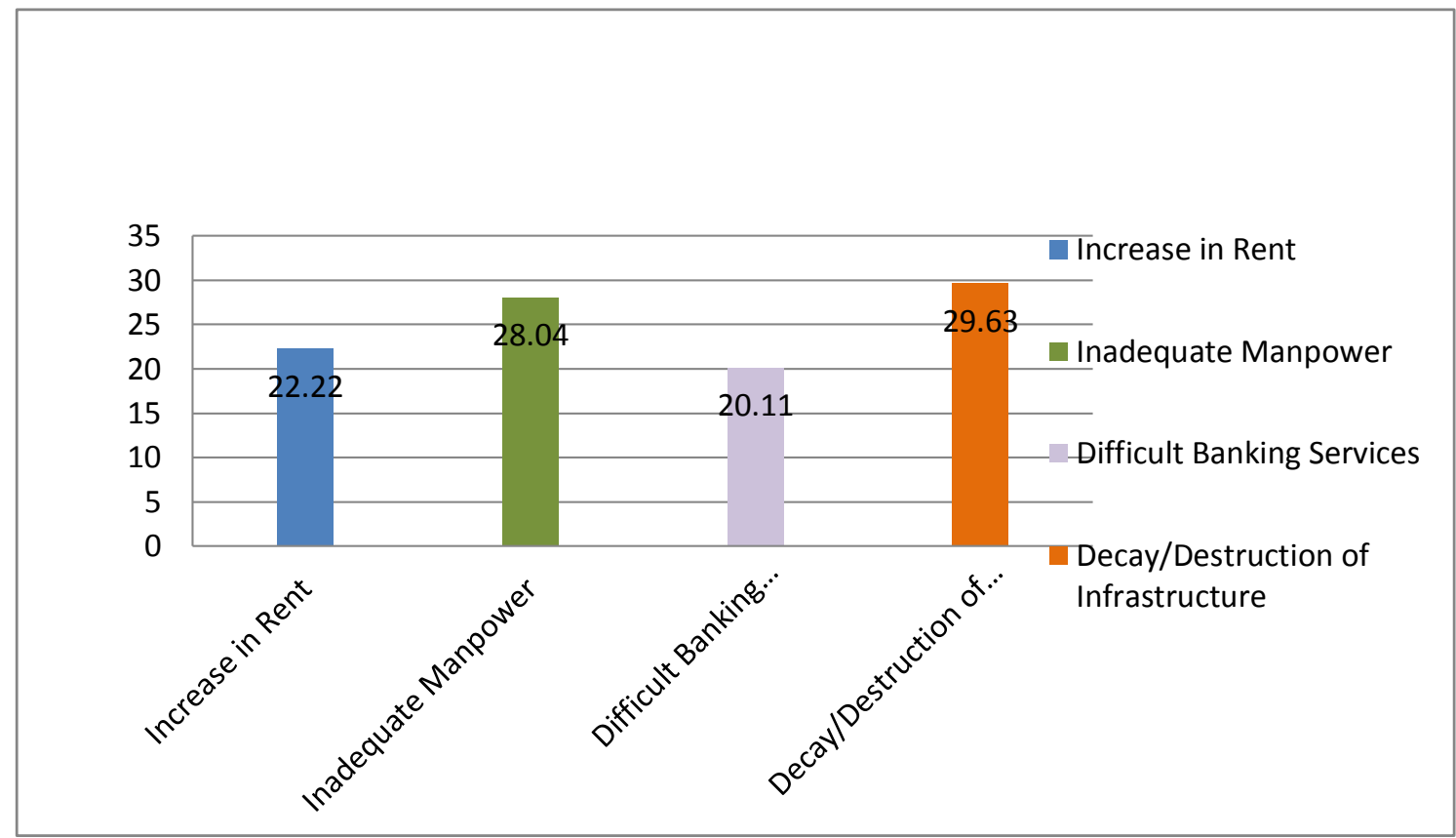

Figure-3. Impact of Ethno-religious Crises on Infrastructures of Wukari Town.

(Source: Field work, 2016)

Figure 3 indicates the impact of Ethno-religious crises on the Infrastructures of Wukari town. The figure shows that the impact is more on the Decay/ Destruction of Infrastructures with (29.63\%).It is followed with inadequate manpower (28.04\%), Increase in Rent (22.22\%) and Difficult Banking Services (20.11\%) respectively.

Response on Effect of Ethno-religious Crises

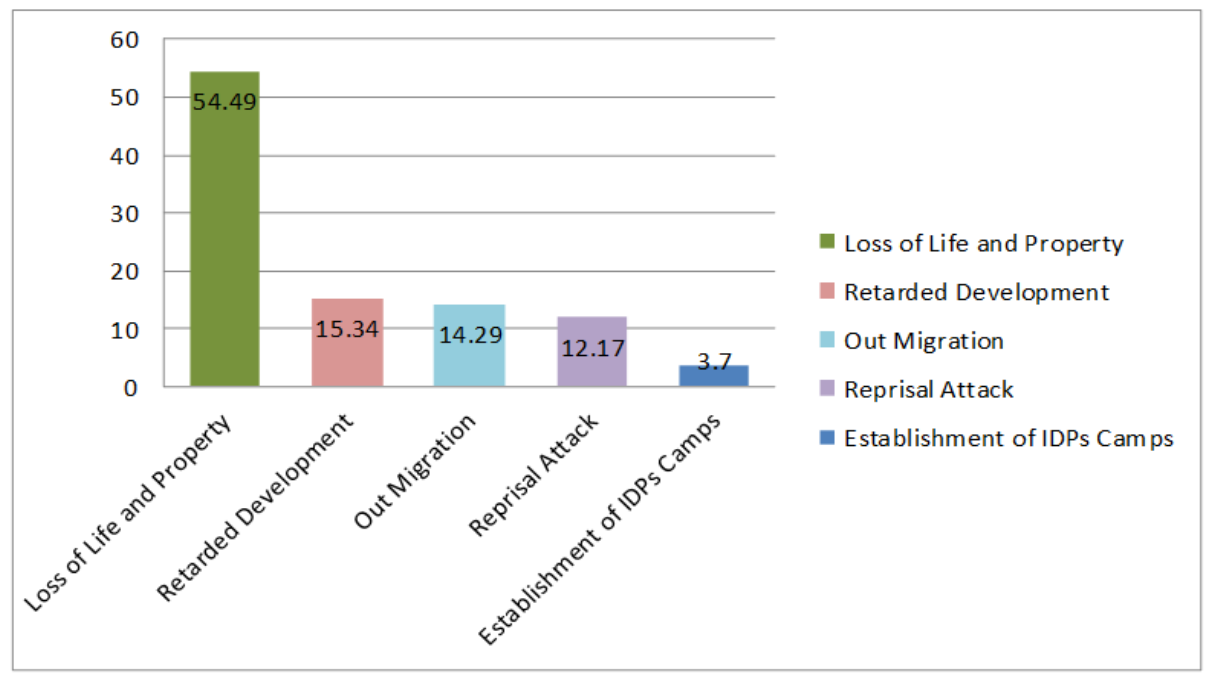

(Source: Field work, 2016).

Figure-4. The Effect of Ethno-religious Crises.

Figure 4 shows the respondents' view on the effect of ethno-religious crises. The figure indicates that the major effect is the Loss of Life and Property (54.49\%).It is followed with Retarded Development (15.34\%), Out Migration (14.29\%), Reprisal Attack (12.17\%) and the Establishment of IDPs Camps (3.7\%) respectively

\subsection{Solution to Avoiding Ethno-Religious Crises}

The table below highlighted the possible solutions to avoiding ethno-religious crises in Wukari. This will assist in mitigating the possible effect on the infrastructures in Wukari and hence accelerates the level of development. 
Table-5. Distribution of Respondents by Response on Solution to Avoiding Ethno-religious Crises.

\begin{tabular}{l|l|l}
\hline Solution & Frequency & Percentage \\
\hline Public Enlightenment & 47 & 24.87 \\
Religious Tolerance & 65 & 34.39 \\
Respect for Cultures of Ethnic Groups & 33 & 17.46 \\
Continuous Dialogue and Peace Initiatives & 29 & 15.34 \\
Avoiding Mutual Suspicion and Fear & 15 & 7.94 \\
\hline Total & 189 & 100.0 \\
\hline Source: Field work, 2016. &
\end{tabular}

From the data in Table 5, suggested possible solution to avoiding further reoccurrences of ethno-religious crises in Wukari town based on views of the respondents include Religious Tolerance (34.39\%), Public Enlightenment (24.87\%), Respect for Cultures of Ethnic Groups (17.46\%), Continuous Dialogue and Peace Initiatives (15.34\%) and Avoiding Mutual Suspicion and fear 7.94\%.

\section{Recommendation/Conclusion}

Based on findings of the study the following are recommended to help mitigate further occurrences of ethno-religious crises in Wukari town;

1. There should be increased level of religious tolerance among the various religious groups in the town.

2. There should also be public enlightenment on how settlers can have respect for cultures of the various ethnic groups found in Wukari town through continuous peace dialogues and initiatives.

3. Interference by political leaders on almost every issue that requires mutual understanding among the various ethnic groups through their religious leaders should be mitigated.

4. The formation of ethnic militia should be discouraged and any discovered group should be brought to law and justice.

5. People should be enlightened and encouraged to avoid mutual suspicion and fear among each other.

Finally, it is important to note that in the absence of peace, development is hindered. Therefore, all stakeholders relevant to maintaining peace in the community must put in their best to ensure continuous coexistence among the people. This remain the only way to development.

\section{References}

Adejumobi, S. (2001). Citizenship, rights and the problem of conflicts and civil wars in Africa. Human Rights Quarterly, No. 23.

Alfa, A. (2012). The challenges of ethno-religious crises to national security. Journal of Nigeria Computer Society.

Ali, A. Y. (2008). Effects of communal conflicts on rural development in Takum and Ussa local government area Taraba State, Nigeria. An Unpublished MSc Thesis Submitted to Department of Geography, Ahmadu Bello University Zaria, Nigeria.

Charles, A., Andeshi, C. A., \& Daniel, W. (2014). War economy of ethno-religious crises: A study of the Wukari crises of Taraba State. Nigeria. International Journal of Peace and Conflict Studies, 2(1), 21-28.

Cochran, W. G. (1977). Sampling techniques (3rd ed.). New York: John Wiley.

Ebukelo, U. J. (2010). Ethno-religious crises in a depressed economy. Ilesha: Oduwani Press Ltd. (ETU Local government toolkit. Adapted from a presentation by Dr. Bonnie Nastasi, Director of School Psychology Program.

Egbetokun, O. A. (2009). Provision of rural infrastructures in Oyo State of Nigeria. Journal of Agricultural Sustainable Practice, 122, 69-70.

Hornby, G. (1995). Working with parents of children with special needs: Cassell.

Mohammed, A. A. (2013). Leadership and ethno-religious crises in Nigeria: A challenge to national development. Lapai International Journal of Politics, 1(1), 172-176.

Mukhtar, T., Arooj, M., Ashfaq, M., \& Gulzar, A. (2017). Resistance evaluation and host status of selected green gram germplasm against Meloidogyne incognita. Crop Protection, 92, 198-202.

National Population Commission. (2010). Federal republic of Nigeria, 2006 population and housing census: Priority Table, Population Distribution by Sex, State, LGA and Senatorial District, 3.

Omofonmwan, S. T. (2004). Health facilities in Esan area of Edo State. A Spatial Perspective Knowledge Review, 8(2), 6-14.

Sullivan, A., \& Steven, M. S. (2003). Economics: Principles in action.

United Nations. (2011). Study on infrastructure for economic development and poverty reduction in Africa. Nairobi. UN Habitat. 